\title{
Istraživanje razlika između percepcije i očekivanja korisnika zdravstvenih usluga primjenom modela SERVQUAL
}

\author{
1 Suzana Marković \\ 1 Irena Regent Turkalj \\ 2 Aleksandar Racz \\ 1 Fakultet za menadžment u turizmu i ugostiteljstvu, \\ Opatija \\ 2 Zdravstveno veleučilište, Zagreb
}

\section{Sažetak}

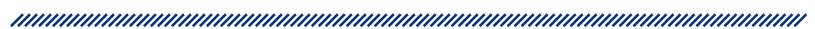

Uvod: Kvaliteta usluga u zdravstvu sve je češće predmet različitih istraživanja. Posebno mjesto u takvim istraživanjima zauzima mjerenje kvalitete zdravstvenih usluga, pri čemu važnu ulogu ima određivanje načina na koji ih percipiraju korisnici.

Cilj i metode: Primjenom prilagođenoga modela SERVQUAL u ovom radu istražena su očekivanja i percepcija 178 korisnika zdravstvenih usluga u Specijalnoj bolnici za medicinsku rehabilitaciju bolesti srca, pluća i reumatizma Thalassotherapia Opatija.

Rezultati: Dimenzije su koje su mjerene ovim istraživanjem: opipljivost, pouzdanost, sigurnost, razumijevanje i odgovornost. Rezultati provedenoga empirijskog istraživanja potvrdili su prikladnost modela SERVQUAL za mjerenje kvalitete zdravstvenih usluga. Utvrđeno je da postoji znatan jaz između percepcija i očekivanja korisnika usluga. Jaz je bio najveći pri ocjeni opipljivosti, tj. fizičkih elemenata pružanja usluga, dok je najmanji jaz kod razumijevanja $(-0,11)$ i sigurnosti $(-0,13)$ te odgovornosti $(-0,17)$, što znači da su korisnici, iako je jaz negativan, ipak dobili očekivanu uslugu. Ispitanici su bili zadovoljni ukupno primljenim uslugama $(6,65 / 7)$ i boravkom te imaju povjerenje u ustanovu uz ocjenu da je zdravstvena usluga premašila očekivanja (6,28/7). Skloni su ustanovu preporučiti drugima (prosječna ocjena tvrdnje 6,65 ), a i sami se ponovno koristiti njezinim uslugama $(6,74 / 7)$. Očekivanja, ali i percepcije, ovise i o spolu, dobi i obrazovanju. Žene imaju veća očekivanja od muškaraca, ali i bolje percipiraju kvalitetu dobivene usluge. Stariji korisnici dobivenu uslugu percipiraju kvalitetnijom od mlađih korisnika. Korisnici s višom razinom obrazovanja statistički značajnije, u odnosu na ostale ispitanike, očekuju da osoblje nađe vremena odgovoriti na njihova pitanja i da razumije njihove specifične potrebe te očekuju točnost u vremenu pružanja usluge. Kada je u pitanju percipirana kvaliteta usluga, statistički značajna razlika ne postoji s obzirom na vrstu korištene medicinske usluge pa se može zaključiti da je ocjena kvalitete usluga Thalassotherapije Opatija slična, bez obzira na vrstu usluge kojom su se ispitanici koristili u ustanovi.

Zaključak: Istraživanje je potvrdilo da je koncept kvalitete zdravstvenih usluga višedimenzionalan te da je uz primjenu modela SERVQUAL moguće na jednostavan i učinkovit način saznati očekivanja, potrebe i želje korisnika zdravstvenih ustanova, kao i njihove stavove o dobivenim uslugama, a zatim ih iskoristiti u svrhu kreiranja kvalitetne ponude.

Ključne riječi: kvaliteta usluga, kvaliteta zdravstvenih usluga, SERVQUAL, statistička analiza, Thalassotherapia Opatija

Datum primitka: 25.10.2018.

Datum prihvaćanja: 31.01.2019.

DOI: $10.24141 / 1 / 5 / 1 / 4$

Adresa za dopisivanje:

doc. dr. sc. Aleksandar Racz, Zdravstveno veleučilište, Zagreb, Mlinarska38,aracz@zvu.hr 


\section{Uvod}

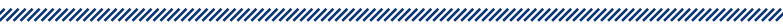

Jedna od češće navođenih definicija kvalitete zdravstvenih usluga jest ona Lohra i Schrödera (2008: 708) prema kojoj je „kvalitetna medicinska zaštita onaj stupanj zaštite pri kojem zdravstvene usluge za pojedinačne pacijente i populaciju povećavaju vjerojatnost željenih zdravstvenih ishoda i koji je u suglasju s tekućim profesionalnim znanjem". Još precizniju definiciju kvalitete u zdravstvu, koja postojećim pridružuje organizacijske, političke i financijske interese, daje Ovretveit (1994: 47), koji navodi da je „kvalitetna medicinska zaštita potpuno zadovoljenje potreba onih koji najviše trebaju zdravstvene usluge, po najmanjem trošku za organizaciju, a unutar ograničenja i smjernica koje postavljaju zdravstvene vlasti i financijeri”. Kvaliteta zdravstvene skrbi može se opisati i kao „stupanj do kojega pružene zdravstvene usluge, u skladu sa sadašnjim profesionalnim znanjem (definiranim standardima), povećavaju vjerojatnost nastanka željenih rezultata" (IOM 1990: 47). Prema Woodwardovu (2000) mišljenju, čimbenici su koji utječu na kvalitetu zdravstvene skrbi: organizacija zdravstvenoga sustava, raspoloživo osoblje, uvođenje promjena, pristup razvijenoj tehnologiji, raspoloživo znanje i vještine, povezanost obrazovnoga sustava i zdravstvenoga sektora te sposobnost apsorpcije i usvajanja novih znanja.

Kvalitetna zdravstvena usluga podrazumijeva, dakle, kvalitetne materijalne, prostorne i ljudske kapacitete te kvalitetne metode rada u obavljanju zdravstvenih postupaka, odnosno pružanju zdravstvenih usluga (Stavljenić-Rukavina 2008). Osim toga, kvaliteta zdravstvene zaštite ovisi i o konačnom rezultatu koji predstavlja mjerljivu promjenu zdravstvenog stanja, kvalitete života i zadovoljstva pacijenata.

Međutim sama kvaliteta pružene usluge ne odgovara nužno i percepciji kvalitete pružene usluge, na koju utječu brojni faktori: od prethodnih iskustava, usmenih predaja i imidža na temelju kojih se formiraju očekivanja, do onoga što i kako korisnik dobiva, odnosno onoga što Grönroos (1984) naziva „tehničkom i funkcionalnom dimenzijom kvalitete". Korisnici percipiranu uslugu uspoređuju s očekivanom i upravo zbog toga cilj je pružatelja usluga premašiti njihova očekivanja kako bi se stvorio zadovoljan korisnik koji će biti lojalan, promicati ugled tvrtke i usluge te privlačiti nove korisnike. Tako se stvara i konkurentska prednost na tržištu. Kada je riječ o uslugama, osobito je teško mjeriti kvalitetu zbog njezinih svojstava: neopipljivosti, nedjeljivosti, promjenjivosti, prolaznosti i raznolikosti (Kotler i sur. 2014: 356). Upravo zbog toga kod mjerenja usluga ključno je identificirati zahtjeve korisnika i njihova očekivanja o kvaliteti usluga. Primjenom teorijskih i empirijskih spoznaja o kvaliteti zdravstvenih usluga i njezinim mjerenjem, moguće je na složen, ali učinkovit način saznati očekivanja, potrebe i želje korisnika zdravstvenih usluga, kao i njihove stavove o dobivenim uslugama te ih upotrijebiti u svrhu kreiranja kvalitetne ponude i unaprjeđenja kvalitete zdravstvenih usluga, a uvođenje mjera za poboljšanje kvalitete zdravstvene skrbi sustavna je obveza svake ustanove i važna za opstojnost zdravstvenog sustava (Stavljenić-Rukavina i Kalanj 2010).

Za mjerenje je moguće primijeniti različite mjerne ljestvice, a jedan je od najvažnijih instrumenata za mjerenje kvalitete usluga model SERVQUAL, koji su razvili Parasuraman, Zeithaml i Berry (1985; 1991; 1988; 1993), a nudi skalu koja sadrži poželjne kvalitete usluga i temelji se na procjeni jaza između očekivanja korisnika o određenoj usluzi i njihove percepcije izvedbe te usluge, odnosno pružatelja usluga. Kvaliteta usluge u modelu SERVQUAL promatra se kao višedimenzionalni konstrukt koji se izvorno sastojao od deset dimenzija, a naknadno su broj dimenzija smanjili na pet: pouzdanost (engl. reliability), sigurnost (engl. assurance), opipljivost (engl. tangibles), razumijevanje (engl. empathy) i odziv (engl. responsiveness). Primjenjuje se za mjerenje kvalitete usluga u nizu uslužnih djelatnosti, pa tako i u zdravstvu i zdravstvenom turizmu (Marković i sur. 2014). U zdravstvu se uglavnom primjenjuje za mjerenje kvalitete s gledišta korisnika usluga. Model polazi od pretpostavke da su za procjenu kvalitete usluge najvažniji korisnici, a njihova procjena temelji se na jazu između očekivanja o određenoj usluzi i njihovoj percepciji o izvedbi te usluge, odnosno pružatelju usluge. Svrha je primjene ovoga instrumenta u pronalaženju tzv. jaza (raskoraka, razlike - engl. gap) između očekivanja korisnika usluge i njegove percepcije o danoj usluzi. Informacije o jazovima između internih i eksternih kvaliteta usluge mogu pomoći menadžerima, odnosno pružateljima usluga da dijagnosticiraju gdje se najbolje mogu ostvariti poboljšanja. Najveći negativni jazovi, kombinirani s procjenom najvećih očekivanja, olakšavaju određivanje prioriteta u poboljšavanju kvalitete usluga. Cilj je menadžera smanjiti raskorak (jaz), uvažavajući da je ono što se mjeri percipirana kvaliteta, koja uvijek predstavlja prosudbu korisnika usluga. Rezultati prethodnih istraživanja provedenih u različitim zemljama primjenom modela SERVQUAL upućuju na zaključak da je to koristan instrument za vrednovanje pružene kvalitete zdravstvenih usluga sa stajališta korisnika te je kao takav primijenjen i u brojnim istraživanjima 
u raznim dijelovima svijeta, npr. Babakus i sur. (1992), Sohal (2003) te u istraživanjima provedenima u Hong Kongu (Lam 1997), Iranu (Zarei i sur. 2015), Africi (Yesilada i Direktör 2010), Mauriciusu (Ramsaran-Fowdar 2013), Kini (Lei i Jolibert 2012), Bangladešu (Rahman i Kutubi 2013), Indiji (Krishnamoorthy i Srinivasan 2014), Gani (Peprah i Atrah 2014) i drugdje (Lee i sur. 2012; Pakdil i Harwood 2005; Karassavidou i sur. 2009; Petrovici i Philips 2009).

\section{Cilj, svrha i hipoteze istraživanja}

Cilj ovoga empirijskog istraživanja bilo je istražiti kvalitetu usluga u Specijalnoj bolnici za medicinsku rehabilitaciju bolesti srca, pluća i reumatizma Thalassotherapia Opatija primjenom modificiranog modela SERVQUAL kroz sljedeće elemente: ocijeniti očekivanja i percepcije korisnika zdravstvenih usluga; utvrditi sociodemografske karakteristike korisnika zdravstvenih usluga; ocijeniti i izračunati SERVQUAL jaz te ocijeniti kvalitetu zdravstvenih usluga; odrediti važnost pojedinih dimenzija kvalitete zdravstvenih usluga; istražiti ima li razlike u važnosti koju korisnici daju pojedinim dimenzijama s obzirom na sociodemografski profil; utvrditi značajnost razlike u prosječnim ocjenama između očekivane i percipirane kvalitete zdravstvenih usluga; utvrditi značajnost razlike u prosječnim ocjenama za očekivanu vrijednost s obzirom na sociodemografski profil korisnika; utvrditi značajnost razlike u prosječnim ocjenama za percipiranu vrijednost s obzirom na sociodemografski profil korisnika te usporediti dobivene rezultate istraživanja s rezultatima iz dosadašnjih stranih i domaćih istraživanja.

Osnovna hipoteza koje je bila testirana u ovom empirijskom istraživanju bila je:

1. Postoje značajna odstupanja između percepcija i očekivanja korisnika zdravstvenih usluga.

Postavljene su i sljedeće pomoćne hipoteze:

2. Korisnici zdravstvenih usluga imaju najviša očekivanja u dimenzijama pouzdanosti i sigurnosti.

3. Korisnici percipiraju nedostatak ljubaznosti zaposlenika u zdravstvenim ustanovama.

4. Korisnici percipiraju nedostatak želje zaposlenika u zdravstvenim ustanovama za pomaganjem i osiguranjem brze usluge.

5. Postoji statistički značajna razlika u prosječnim ocjenama za očekivanu vrijednost s obzirom na dob korisnika.

6. Postoji statistički značajna razlika u prosječnim ocjenama za percipiranu vrijednost s obzirom na dob korisnika.
7. Ne postoji statistički značajna razlika u prosječnim ocjenama za očekivanu vrijednost s obzirom na spol korisnika.

8. Ne postoji statistički značajna razlika u prosječnim ocjenama za percipiranu vrijednost s obzirom na spol korisnika.

9. Postoji statistički značajna razlika u prosječnim ocjenama za očekivanu vrijednost s obzirom na razinu obrazovanja korisnika.

10. Postoji statistički značajna razlika u prosječnim ocjenama za percipiranu vrijednost s obzirom na razinu obrazovanja korisnika.

11. Ne postoji statistički značajna razlika u prosječnim ocjenama za očekivanu i percipiranu vrijednost s obzirom na vrstu korištene medicinske usluge.

\section{Metodologija istraživanja}

Istraživanje zadovoljstva korisnika zdravstvenih usluga provedeno je primjenom modificiranog modela SERVQUAL za mjerenje kvalitete usluga. Primarni podaci dobiveni su metodom anketiranja korisnika zdravstvenih usluga u Specijalnoj bolnici za medicinsku rehabilitaciju bolesti srca, pluća i reumatizma Thalassotherapia Opatija.

Mjerni instrument istraživanja bio je anketni upitnik. Anketni upitnik sastojao se od četiri cjeline te je sadržavao ukupno 78 čestica. Struktura anketnoga upitnika prikazana je u tablici 1 .

\begin{tabular}{|c|c|c|}
\hline KONCEPT & $\begin{array}{l}\text { LJESTVICA } \\
\text { MJERENJA }\end{array}$ & $\begin{array}{c}\text { BROJ } \\
\text { ČESTICA }\end{array}$ \\
\hline $\begin{array}{c}\text { Očekivanje } \\
\text { kvalitete usluga }\end{array}$ & $\begin{array}{l}\text { Likertova ljestvica } \\
\qquad(1-7)\end{array}$ & 33 \\
\hline $\begin{array}{c}\text { Percepcija } \\
\text { kvalitete usluga }\end{array}$ & $\begin{array}{l}\text { Likertova ljestvica } \\
\qquad(1-7)\end{array}$ & 33 \\
\hline Zadovoljstvo korisnika & $\begin{array}{l}\text { Likertova ljestvica } \\
\qquad(1-7)\end{array}$ & 2 \\
\hline Lojalnost korisnika & $\begin{array}{l}\text { Likertova ljestvica } \\
\qquad(1-7)\end{array}$ & 2 \\
\hline Demografski podaci & $\begin{array}{c}\text { Nominalna, } \\
\text { ordinalna } \\
\text { i omjerna ljestvica }\end{array}$ & 8 \\
\hline
\end{tabular}


U prvom su dijelu, s pomoću 33 tvrdnje, ocijenjena očekivanja korisnika o kvaliteti usluga u zdravstvenoj ustanovi. Drugi dio anketnoga upitnika sastojao se od 33 sukladne tvrdnje i odnosio se na ocjenu percepcije kvalitete usluga. Osnova anketnoga upitnika bio je instrument SERVQUAL koji su sastavili Parasuraman, Zeithaml i Berry $(1985 ; 1988 ; 1991)$, no s obzirom na to da je ovo istraživanje provedeno u zdravstvenoj ustanovi, upitnik je modificiran i proširen s 12 dodatnih tvrdnji (tvrdnje 4, 6, 7, 8, 18, 24, 28 - 33) koje su prilagođene specifičnostima usluga zdravstvene ustanove u kojoj je istraživanje provedeno. $U$ trećem dijelu anketnoga upitnika ocjenjivano je zadovoljstvo i lojalnost ispitanika kroz četiri tvrdnje, po dvije za svaku komponentu. Tvrdnje za zadovoljstvo bile su: „Zadovoljan sam ukupnom uslugom ustanove” i „Zdravstvena usluga premašila je moja očekivanja”. Tvrdnje za lojalnost bile su: „Ustanovu ću preporučiti prijateljima” i „Ako budem imao/ la potrebe i prilike, ponovno ću boraviti u ovoj ustanovi". Korisnici uključeni u istraživanje tvrdnje sadržane u prve tri cjeline mjernoga instrumenta ocjenjivali su na Likertovoj ljestvici sa 7 ocjena, s krajnjim mjerama „potpuno se ne slažem” (1) i „potpuno se slažem” (7).

Četvrti dio anketnoga upitnika odnosio se na sociodemografske podatke korisnika: dob, spol, zanimanje, obrazovanje, razlog dolaska u zdravstvenu ustanovu, područje korištene medicinske usluge, duljinu boravka i učestalost dolazaka u zdravstvenu ustanovu.

U tablici 2 prikazana je struktura korištenoga višedimenzionalnog modela za ocjenjivanje kvalitete usluga. Ukratko je opisana svaka dimenzija te je naveden broj tvrdnji za svaku pojedinu dimenziju.

Dimenzija opipljivosti odnosila se na fizičku dimenziju usluge, odnosno stanje zgrade, opreme i izgleda osoblja te je ocjenjivana kroz 12 tvrdnji. Pouzdanost se odnosila na sposobnost realizacije obećane usluge točno i odgovorno te je mjerena sa šest tvrdnji. Dimenzija sigurnosti odnosila se na znanje i ljubaznost osoblja te njihovu sposobnost da ulijevaju povjerenje korisnicima i mjerena je s pet tvrdnji. Razumijevanje je podrazumijevalo brižnost i individualiziranu pažnju prema korisniku/ klijentu i ocjenjivano je kroz pet tvrdnji. Odgovornost se odnosila na voljnost osoblja da trenutačno pruži uslugu ili pomoć i također je ocjenjivana kroz pet tvrdnji.

Podaci su prikupljani metodom osobnoga ispitivanja u Specijalnoj bolnici za medicinsku rehabilitaciju bolesti srca, pluća i reumatizma Thalassotherapia Opatija u razdoblju od 1. do 31. listopada 2014. Anketni upitnik dostavljen je u podjednakom broju stacionarnim korisnicima na odjelima kardiološke i fizikalne rehabilitacije koji su se koristili uslugama smještaja u ustanovi te korisnicima koji su došli na preglede i rehabilitaciju bez usluga smještaja. Podijeljeno je ukupno 220 anketnih upitnika. Prikupljen je ukupno 181 anketni upitnik, od čega je 178 upitnika bilo pravilno popunjeno, odnosno $80,90 \%$ ukupnog broja podijeljenih anketnih upitnika.

\section{Rezultati}

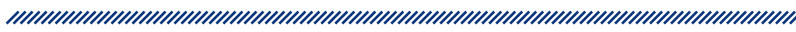

Rezultati statističke analize podataka prikazani su kako slijedi. Prvo je opisan uzorak ispitanika, nakon čega su prikazani rezultati deskriptivne statističke analize te slijedi prikaz rezultata bivarijatne statističke analize (ttesta i analize varijance).

Iz tablice 3 vidljivo je da je među 178 korisnika obuhvaćenih istraživanjem bila veća zastupljenost muškaraca $(55,6 \%)$ u odnosu na žene $(44,4 \%)$. Dobna struktura ispitanih korisnika podijeljena je u šest skupina. Najveći broj čine oni starije životne dobi, 43,3\% korisnika bilo je starije od 65 godina. Slijede korisnici u dobi od 56 do 65 godina, oni čine $27 \%$ uzorka. U srednjoj dobi, od 46 do

\begin{tabular}{|c|c|c|}
\hline \multicolumn{2}{|c|}{ Tablica 2. Prikaz korištenih tvrdnji po pojedinim dimenzijama } \\
\hline DIMENZIJE & OPIS DIMENZIJE & BROJ TVRDNJI \\
\hline Opipljivost & Fizička dimenzija usluge: stanje zgrade, opreme, izgled osoblja & 12 \\
\hline Pouzdanost & Sposobnost realizacije obećane usluge točno i odgovorno & 6 \\
\hline Sigurnost & Znanje, ljubaznost osoblja te njihova sposobnost da ulijevaju povjerenje & 5 \\
\hline Razumijevanje & korisnicima & 5 \\
\hline Odgovornost & Voljnost osoblja da trenutačno pruži uslugu ili pomoć & 5 \\
\hline
\end{tabular}




\section{Tablica 3. Profil ispitanika ( $\mathbf{N}=\mathbf{1 7 8})$}

\begin{tabular}{|c|c|c|}
\hline \multirow{2}{*}{ OPIS } & \multicolumn{2}{|c|}{ FREKVENCIJE } \\
\hline & APSOLUTNE & RELATIVNE (\%) \\
\hline \multicolumn{3}{|l|}{ Dob } \\
\hline $16-25$ godina & 0 & 0,0 \\
\hline $26-35$ godina & 6 & 3,4 \\
\hline $36-45$ godina & 18 & 10,1 \\
\hline $46-55$ godina & 29 & 16,3 \\
\hline $56-65$ godina & 48 & 27,0 \\
\hline 66 i više godina & 77 & 43,3 \\
\hline \multicolumn{3}{|l|}{ Spol } \\
\hline Muški & 99 & 55,6 \\
\hline Ženski & 79 & 44,4 \\
\hline \multicolumn{3}{|l|}{ Zanimanje } \\
\hline Zaposlen & 67 & 37,6 \\
\hline Nezaposlen & 10 & 5,6 \\
\hline Učenik/student & 0 & 0 \\
\hline Umirovljenik & 101 & 56,7 \\
\hline \multicolumn{3}{|l|}{ Obrazovanje } \\
\hline Osnovna škola & 11 & 6,2 \\
\hline Srednja škola & 94 & 52,8 \\
\hline Viša škola ili fakultet & 67 & 37,6 \\
\hline Ostalo & 6 & 3,4 \\
\hline \multicolumn{3}{|l|}{ Razlog dolaska } \\
\hline Pregled ili dijagnostička pretraga & 78 & 43,8 \\
\hline Medicinski i zdravstveni programi & 88 & 49,4 \\
\hline Preventivna medicina i wellness & 10 & 5,6 \\
\hline Odmor i opuštanje & 1 & 0,6 \\
\hline Aktivan odmor & 0 & 0,0 \\
\hline Ljepota i privlačnost destinacije & 1 & 0,6 \\
\hline \multicolumn{3}{|l|}{ Područje korištene medicinske usluge } \\
\hline Kardiologija & 138 & 77,5 \\
\hline Fizikalna medicina i reumatologija & 30 & 16,9 \\
\hline Sportska medicina & 2 & 1,1 \\
\hline Dermatologija, neurologija, radiologija, dijetoterapija & 8 & 4,5 \\
\hline \multicolumn{3}{|l|}{ Duljina boravka } \\
\hline Nekoliko sati & 79 & 44,4 \\
\hline $1-7$ dana & 15 & 8,4 \\
\hline $8-15$ dana & 19 & 10,7 \\
\hline Više od 15 dana & 65 & 36,5 \\
\hline \multicolumn{3}{|l|}{ Broj prethodnih boravaka u objektu } \\
\hline Nikada & 56 & 31,5 \\
\hline 1 put & 49 & 27,5 \\
\hline 2 ili više puta & 67 & 37,6 \\
\hline Ostalo & 6 & 3,4 \\
\hline
\end{tabular}


Marković S. i sur. Istraživanje razlika između percepcije i očekivanja korisnika s modelom SERVQUAL. J. appl. health sci. 2019; 5(1): 41-59

55 godina, bilo je 16,3\% korisnika te $10,1 \%$ u dobi od 36 do 45 godina. Najmanji broj ispitanih korisnika $(3,4 \%)$ bilo je u dobnoj skupini od 26 do 35 godina, dok mlađih korisnika od 26 godina u ovom uzorku nije bilo.

Većina ispitanih korisnika (56,7 \%) bili su umirovljenici, slijede zaposleni (37,6 \%) te nezaposleni (5,6 \%). U uzorku nije bilo nijednog učenika ili studenta. Prema stupnju obrazovanja, više od polovine korisnika imalo je završeno srednjoškolsko obrazovanje $(52,8 \%)$, slijede korisnici sa završenom višom školom ili fakultetom $(37,6 \%)$, korisnici sa završenom osnovnom školom $(6,2 \%)$ te ostali $(3,4 \%)$.

Korisnici uključeni u istraživanje imali su mogućnost izabrati više od jednog razloga dolaska u navedenu zdravstvenu ustanovu. Gotovo svi (93,2 \%) kao razlog dolaska naveli su neki od medicinskih razloga, od toga je 49,4\% navelo medicinske i zdravstvene programe, a 43,8 \% pregled ili dijagnostičku pretragu. Preventivna medicina i wellness predstavljali su razlog dolaska kod 5,6 \% ispitanih korisnika. Odmor i opuštanje te ljepotu i privlačnost destinacije izabralo je svega 1,2 \% korisnika, dok aktivan odmor nitko od korisnika nije označio kao razlog dolaska. Većina korisnika $(77,5 \%)$ došla je zbog korištenja medicinskim uslugama iz kardiologije. Znatno manji dio korisnika (16,9 \%) označio je korištenje medicinskim uslugama fizikalne medicine i reumatologije. Medicinskim uslugama iz dermatologije, neurologije, radiologije i dijetoterapije koristilo se 4,5\% uključenih u ispitivanje, a neznatan dio ispitanika uslugama sportske medicine (1,1\%).

Prema duljini boravka, vidljivo je da je najveći broj ispitanih korisnika $(44,4 \%)$ došao na nekoliko sati obaviti pregled ili dijagnostičku pretragu. Više od 15 dana u ustanovi je boravilo $36,5 \%$ korisnika, slijede korisnici koji su u ustanovi boravili od 8 do 15 dana (10,7 \%). Najmanji broj korisnika boravio je u ustanovi od 1 do 7 dana (8,4\%). Većina korisnika već je ranije boravila u ustanovi $(65,1 \%)$, od toga je 37,6 \% korisnika boravilo već dva ili više puta. Prvi je put ustanovu posjetilo 31,5 \% korisnika, a 5,6 \% ispitanika označilo je kategoriju „ostalo”.

Analizom uzorka definirane su osnovne demografske značajke korisnika zdravstvenih usluga koji su sudjelovali u ovom empirijskom istraživanju. Utvrđeno je da u uzorku ima nešto više muškaraca od žena. Većina je srednje i starije životne dobi i imaju srednje ili više i visoko obrazovanje. Osnovni je razlog dolaska korištenje medicinskim uslugama iz kardiologije.

Iz tablice 4 uočljivo je da su ispitani korisnici imali visoka očekivanja kvalitete usluge u zdravstvenoj usta- novi. Prosjek ocjene na ljestvici očekivanja iznosi 6,69. Međutim, i ocjene percepcije kvalitete usluga relativno su visoke, prosjek ocjene na ljestvici percepcije iznosi 6,48 . Iz navedenoga je utvrđen SERVQUAL jaz koji u odnosu na prosječne ocjene očekivanja i percepcije iznosi $-0,21$.

Vidljivo je da kod svih tvrdnji osim zadnje prevladavaju negativne vrijednosti izračunanoga jaza, što znači da su očekivanja veća od percepcije pa je percipirana kvaliteta nezadovoljavajuća, zbog čega se pojavljuje jaz kvalitete. Zadnja tvrdnja, koja se odnosi na prepoznatljivi imidž, ima pozitivnu vrijednost jaza $(+0,04)$. To znači da je prosječna ocjena percepcije bila nešto veća od prosječne ocjene očekivanja.

Tablica 5 prikazuje prosječne ocjene očekivanja i percepcije kvalitete, sa SERVQUAL jazovima za svaku pojedinu dimenziju. Kod svih dimenzija kvalitete usluge postoji jaz između percepcija i očekivanja (od $-0,11$ do $-0,32$ ), a najveći jaz uočen je kod dimenzije „opipljivost”. To pokazuje da su korisnici imali najveća očekivanja u odnosu na percepcije kod dimenzije „opipljivost”, vjerojatno zbog jednostavne i brze procjene elemenata koji čine tu dimenziju (oprema, prostori zdravstvene ustanove, odjeća osoblja i sl.). Najmanji jaz uočen je kod dimenzije „razumijevanje”, zatim slijede „sigurnost" i „odgovornost”, što nam pokazuje da se kod tih dimenzija percepcija najviše približila očekivanjima.

Izdvajajući u tablici 4 pet najbolje ocijenjenih tvrdnji za ljestvicu očekivanja i ljestvicu percepcije može se uočiti da je najveću prosječnu ocjenu $(6,90)$ na ljestvici očekivanja ostvarila tvrdnja „Pribor i uređaji u ZU-u moraju biti čisti." Iduća tvrdnja s najvišom ocjenom također govori u prilog da ispitanici očekuju od zdravstvenih ustanova da budu čiste i uredne. Iduće tri tvrdnje s najvišim prosječnim ocjenama na ljestvici očekivanja odnose se na stručnost, urednost i povjerenje koje ulijeva osoblje u zdravstvenoj ustanovi, što govori o važnosti kvalitete osoblja u djelatnosti ustanove.

$\mathrm{Na}$ ljestvici percepcije tvrdnja „Ustanova TTO je uredna i čista" ostvarila je najveću prosječnu ocjenu $(6,75)$, slijedi tvrdnja „Pribor i uređaji u TTO-u su čisti.” To su ujedno najbolje ocijenjene tvrdnje s ljestvice očekivanja, što govori da korisnici usluga doživljavaju čistoću i urednost ustanove kao vrlo važnu stavku. Iduće tri najbolje ocijenjene tvrdnje na ljestvici percepcije odnose se na znanje, sigurnost i povjerenje koje ulijeva osoblje zdravstvene ustanove. Upravo to su karakteristike osoblja za koje su ispitanici imali i visoka očekivanja, uz napomenu da su jazovi negativni. 


\section{Tablica 4. Rezultati deskriptivne statističke analize $(\mathbf{N}=\mathbf{1 7 8})$}

\begin{tabular}{|c|c|c|c|c|c|c|}
\hline & \multicolumn{2}{|c|}{ OČEKIVANJA } & \multicolumn{2}{|c|}{ PERCEPCIJA } & \multirow{2}{*}{$\begin{array}{l}\text { SERVQUAL } \\
\text { jaz }\end{array}$} \\
\hline & Čestica (tvrdnja) & $\begin{array}{l}\text { Prosječna } \\
\text { ocjena }\end{array}$ & $\begin{array}{l}\text { Standardna } \\
\text { devijacija }\end{array}$ & $\begin{array}{l}\text { Prosječna } \\
\text { ocjena }\end{array}$ & $\begin{array}{l}\text { Standardna } \\
\text { devijacija }\end{array}$ & \\
\hline 1. & Moderna oprema & 6,42 & 1,098 & 6,21 & 1,140 & $-0,21$ \\
\hline 2. & Atraktivan izgled zgrada i prostorija & 6,04 & 1,425 & 6,01 & 1,246 & $-0,03$ \\
\hline 3. & Uredno osoblje & 6,87 & 0,403 & 6,68 & 0,605 & $-0,19$ \\
\hline 4. & Ugodan inventar i namještaj & 6,46 & 1,042 & 6,10 & 1,276 & $-0,36$ \\
\hline 5. & Čisti pribor i uređaji & 6,90 & 0,348 & 6,74 & 0,585 & $-0,16$ \\
\hline 6. & Čista i uredna zdravstvena ustanova & 6,89 & 0,493 & 6,75 & 0,516 & $-0,14$ \\
\hline 7. & $\begin{array}{l}\text { Raspolaganje opremom i objektima u skladu } \\
\text { s uslugama koje pruža ZU }\end{array}$ & 6,58 & 0,978 & 6,42 & 0,906 & $-0,16$ \\
\hline 8. & Laka dostupnost (parkiralište, dizala i sl.) & 6,69 & 0,838 & 5,17 & 1,904 & $-1,52$ \\
\hline 9. & Pravodobno izvršavanje obećanja & 6,76 & 0,681 & 6,36 & 0,936 & $-0,40$ \\
\hline 10. & Razumijevanje za probleme klijenata & 6,81 & 0,560 & 6,58 & 0,653 & $-0,23$ \\
\hline 11. & Pružanje usluge korektno već u prvom pokušaju & 6,82 & 0,533 & 6,65 & 0,632 & $-0,17$ \\
\hline 12. & Ustanova pruža usluge u obećanom vremenu & 6,75 & 0,733 & 6,55 & 0,672 & $-0,20$ \\
\hline 13. & Vođenje dokumentacije bez pogrešaka & 6,84 & 0,440 & 6,63 & 0,652 & $-0,21$ \\
\hline 14. & $\begin{array}{c}\text { Obavještavanje klijenata o točnom vremenu } \\
\text { pružanja usluge }\end{array}$ & 6,82 & 0,522 & 6,67 & 0,634 & $-0,15$ \\
\hline 15. & Osoblje pruža brze usluge & 6,74 & 0,632 & 6,48 & 0,825 & $-0,26$ \\
\hline 16. & Osoblje je spremno pomoći klijentima & 6,84 & 0,477 & 6,68 & 0,623 & $-0,16$ \\
\hline 17. & $\begin{array}{l}\text { Osoblje nalazi vremena odgovoriti klijentu } \\
\text { na pitanje }\end{array}$ & 6,73 & 0,709 & 6,60 & 0,659 & $-0,13$ \\
\hline 18. & Osoblje pruža usluge bez kašnjenja & 6,57 & 0,925 & 6,44 & 0,837 & $-0,13$ \\
\hline 19. & Ulijevanje povjerenja & 6,88 & 0,407 & 6,70 & 0,627 & $-0,18$ \\
\hline 20. & Osjećaj sigurnosti i bezbrižnosti & 6,75 & 0,558 & 6,70 & 0,569 & $-0,05$ \\
\hline 21. & Ljubazno osoblje & 6,80 & 0,521 & 6,66 & 0,688 & $-0,14$ \\
\hline 22. & Osoblje zna odgovoriti na pitanja klijenta & 6,76 & 0,585 & 6,69 & 0,657 & $-0,07$ \\
\hline 23. & Ustanova pruža individualnu pažnju & 6,55 & 0,951 & 6,54 & 0,796 & $-0,01$ \\
\hline 24. & Stručno pružanje usluga & 6,89 & 0,360 & 6,69 & 0,629 & $-0,20$ \\
\hline 25. & Osoblje pruža individualiziranu pažnju & 6,58 & 0,841 & 6,57 & 0,815 & $-0,01$ \\
\hline 26. & $\begin{array}{l}\text { Brižljivo vođenje računa o interesima } \\
\text { klijenata }\end{array}$ & 6,74 & 0,681 & 6,59 & 0,733 & $-0,15$ \\
\hline 27. & Razumijevanje specifičnih potreba klijenata & 6,62 & 0,697 & 6,58 & 0,661 & $-0,04$ \\
\hline 28. & Jednostavno snalaženje po ustanovi & 6,72 & 0,629 & 6,18 & 1,263 & $-0,54$ \\
\hline 29. & Informacije su dostupne, jednostavne i jasne & 6,81 & 0,496 & 6,47 & 0,730 & $-0,34$ \\
\hline 30. & Ponuda različitih medicinskih programa & 6,53 & 1,037 & 6,51 & 0,797 & $-0,02$ \\
\hline 31. & $\begin{array}{l}\text { Ponuda različitih sportsko-rekreacijskih } \\
\text { programa }\end{array}$ & 6,30 & 1,243 & 6,18 & 1,184 & $-0,12$ \\
\hline 32. & $\begin{array}{l}\text { Ponuda je prilagođena suvremenim } \\
\text { trendovima i potrebama klijenata }\end{array}$ & 6,71 & 0,640 & 6,38 & 0,896 & $-0,33$ \\
\hline 33. & Prepoznatljiv imidž & 6,62 & 0,788 & 6,66 & 0,737 & $+0,04$ \\
\hline & Ukupno & 6,69 & - & 6,48 & - & $-0,21$ \\
\hline
\end{tabular}


Tablica 5. Prosječne ocjene očekivanja i percepcije prema dimenzijama modela SERVQUAL

\begin{tabular}{|c|c|c|c|}
\hline DIMENZIJE MODELA & LJESTVICA OČEKIVANJA & LJESTVICA PERCEPCIJE & \multirow{2}{*}{ SERVQUAL JAZ } \\
\cline { 2 - 3 } SERVQUAL & Prosječna ocjena & Prosječna ocjena & $-0,32$ \\
\hline Opipljivost & 6,60 & 6,28 & $-0,20$ \\
\hline Pouzdanost & 6,77 & 6,57 & $-0,13$ \\
\hline Sigurnost & 6,81 & 6,68 & $-0,11$ \\
\hline Razumijevanje & 6,64 & 6,53 & $-0,17$ \\
\hline Odgovornost & 6,74 & 6,57 & \\
\hline Napomena: Ljestvica ocjenjivanja obuhvaća sedam ocjena, gdje je ocjena 1 najniža ocjena, a ocjena 7 najviša ocjena. & \\
\hline
\end{tabular}

Također, analiza pet najlošije ocijenjenih tvrdnji prikazanih u tablici 4 na ljestvici očekivanja ukazuje na to da se tri odnose na atraktivnost zgrade i prostorija, opremu modernog izgleda i ugodan inventar i namještaj, što govori da u tom dijelu ponude ispitanici imaju najmanja očekivanja. Ostale dvije tvrdnje s najlošijim prosječnim ocjenama na ljestvici očekivanja odnose se na ponudu različitih sportsko-rekreacijskih i medicinskih programa, što i nije iznenađujuće s obzirom na to da je većina korisnika uključenih u istraživanje $(93,2 \%)$ došla u ustanovu na već dogovoreni pregled, dijagnostičku pretragu, liječenje ili rehabilitaciju te nije ni imala potrebu birati različite sportske ili medicinske programe.

Na ljestvici percepcije najmanju prosječnu ocjenu 5,17 ostvarila je tvrdnja „Ustanova TTO je lako dostupna (parkirališna mjesta, dizala i sl.)". S tim povezana tvrdnja „Omogućeno je jednostavno snalaženje po TTO-u” također je među pet najlošije ocijenjenih tvrdnji na ljestvici percepcije.

Preostale tri najlošije ocijenjene tvrdnje o atraktivnosti prostora, ugodnom inventaru i namještaju te ponudi sportsko-rekreacijskih programa nalaze se i među najlošije ocijenjenim tvrdnjama na ljestvici očekivanja. $\mathrm{Na}$ temelju toga može se zaključiti da ih korisnici usluga ne smatraju vrlo važnim dijelom ponude.

Tvrdnja kod koje su ispitani korisnici iskazali najveći jaz između očekivanja kvalitete usluga pri dolasku u zdravstvenu ustanovu i percepcije kvalitete usluga tijekom boravka u zdravstvenoj ustanovi jest tvrdnja percepcije: „Ustanova TTO je lako dostupna (parkirališna mjesta, dizala i sl.)” (-1,52), slijedi tvrdnja: „Omogućeno je jednostavno snalaženje po TTO-u" $(-0,54)$. Među pet tvrdnji s najvećim jazom nalazi se i tvrdnja: „Informacije u TTO-u dostupne su, jednostavne i jasne" $(-0,34)$. Navedeni rezultati upućuju na zaključak da najveći jaz nije povezan s osnovnim medicinskim uslugama koje pruža zdravstvena ustanova, već uz popratne usluge parkira- lišta, dizala i svega drugoga što olakšava i pojednostavljuje snalaženje po zdravstvenoj ustanovi. Ni preostale dvije tvrdnje s najvećim jazom: „U TTO-u se obećanja izvršavaju na vrijeme” i „TTO ima ugodan inventar i namještaj" nisu povezane s osnovnom medicinskom uslugom zdravstvene ustanove.

U skladu s iznesenom analizom tablice 4 mogu se izdvojiti tvrdnje s najvećim i najmanjim jazom. Tvrdnja „TTO ima prepoznatljiv imidž" jedina je tvrdnja na ljestvici percepcije koja ima pozitivan jaz $(+0,04)$, što govori da je percepcija imidža ustanove na višoj razini od očekivanja. Ostale četiri tvrdnje s najmanjim jazom, odnosno najmanjim raskorakom između očekivanja i percepcije povezane su s individualiziranom pažnjom koju ustanova i osoblje pružaju korisnicima, različitosti medicinskih programa koje ustanova nudi te atraktivnošću prostora.

$\mathrm{U}$ tablici 6 navedene su prosječne ocjene zadovoljstva i lojalnosti ispitanika.

Iz prikazanih rezultata u tablici 6 možemo zaključiti da su korisnici zdravstvenih usluga Specijalne bolnice za medicinsku rehabilitaciju bolesti srca, pluća i reumatizma Thalassotherapia Opatija općenito vrlo zadovoljni primljenim uslugama i boravkom u bolnici te da je zadobiveno visoko povjerenje korisnika usluga. Ispitanici su zadovoljstvo ukupnom uslugom ustanove ocijenili s visokom prosječnom ocjenom 6,65 od maksimalnih 7 bodova. Tvrdnja „Zdravstvena usluga premašila je moja očekivanja” također je ocijenjena visokom prosječnom ocjenom 6,28.

Tvrdnje vezane za lojalnost korisnika: „Ustanovu ću preporučiti prijateljima” i „Ako budem imao/la potrebe i prilike, ponovno ću boraviti u ovoj ustanovi" ocijenjene su visokim prosječnim ocjenama 6,65 i 6,74 od ukupnih 7 bodova, što dokazuje da su korisnici prepoznali ukupnu kvalitetu usluga i da će svoje zadovoljstvo prenijeti drugima te se i sami ponovno koristiti uslugama zdravstvene ustanove. 


\section{Tablica 6. Rezultati deskriptivne analize zadovoljstva i lojalnosti ispitanika $(\mathbf{N}=\mathbf{1 7 8})$}

\begin{tabular}{|c|c|c|c|c|c|}
\hline & & Minimum & Maksimum & $\begin{array}{c}\text { Prosječna } \\
\text { ocjena }\end{array}$ & $\begin{array}{l}\text { Standardna } \\
\text { devijacija }\end{array}$ \\
\hline \multicolumn{6}{|c|}{ Zadovoljstvo korisnika } \\
\hline 1. & Zadovoljan sam ukupnom uslugom ustanove. & 3 & 7 & 6,65 & 0,684 \\
\hline 2. & Zdravstvena usluga premašila je moja očekivanja. & 1 & 7 & 6,28 & 1,058 \\
\hline \multicolumn{6}{|c|}{ Lojalnost korisnika } \\
\hline 3. & Ustanovu ću preporučiti prijateljima. & 2 & 7 & 6,65 & 0,753 \\
\hline 4. & $\begin{array}{l}\text { Ako budem imao/la potrebe i prilike, ponovno ću } \\
\text { boraviti u ovoj ustanovi. }\end{array}$ & 2 & 7 & 6,74 & 0,715 \\
\hline
\end{tabular}

Bivarijatnom statističkom analizom željela se utvrditi značajnost razlike između aritmetičkih sredina više promatranih skupina. U svrhu testiranja značajnosti razlike korišten je t-test za nezavisne uzorke (engl. independent samples ttest), u cilju utvrđivanja postoji li statistički značajna razlika između prosječnih ocjena za očekivanu i percipiranu vrijednost s obzirom na dob i spol ispitanih korisnika usluga.

Prije provedbe testa korisnici uključeni u istraživanje grupirani u su dvije skupine s obzirom na dob. Prva skupina obuhvatila je mlađe korisnike, odnosno one u dobi do 55 godina. Njih je u uzorku bilo 53 ili 29,8 \%. Druga skupina obuhvatila je korisnike starije od 55 godina kojih je u uzorku bilo 125, odnosno 70,2 \%. Rezultati provedenog t-testa prikazani su u tablici 7 , koja pokazuje da stariji korisnici zdravstvenih usluga imaju viša očekivanja od mlađih korisnika.

Nakon što nije potvrđeno da postoji statistički značajna razlika u očekivanjima s obzirom na dob korisnika, izvršena je provjera razlike u prosječnim ocjenama ispi- tanih korisnika na ljestvici percepcije s obzirom na dob. Primjenom t-testa za nezavisne uzorke uspoređene su ocjene percepcije u ranije definiranim dobnim skupinama, a rezultati prikazani su u tablici 8 .

Vidljivo je da su prosječne ocjene percepcije više kod starijih korisnika u odnosu na mlađe. Razlika prosječnih ocjena na ljestvici percepcije iznosila je 0,24 i statistički je značajna $(p<0,05)$.

$\mathrm{U}$ ispitivanom uzorku korisnika zdravstvenih usluga bilo je više muškaraca, njih 99 ili 55,6 \%. Žena je u ispitivanom uzorku bilo 79 , odnosno $44,4 \%$. Pretpostavljeno je kako nema razlike u očekivanjima kvalitete usluga $\mathrm{s}$ obzirom na spol korisnika, a kako bi se ispitalo postoji li statistički značajna razlika između te dvije skupine ispitanih korisnika, proveden je t-test za nezavisne uzorke. Rezultati testa prikazani su tablicom 9 i može se uočiti da postoji razlika u ocjenama te da je ta razlika statistički značajna $(p<0,05)$. Naime, žene su imale višu prosječnu ocjenu očekivanja od muškaraca.

\begin{tabular}{|c|c|c|c|c|}
\hline ČESTICA & $\begin{array}{c}\text { Pacijenti } \\
\text { do } 55 \text { godina } \\
\text { (A.S.) }\end{array}$ & $\begin{array}{l}\text { Pacijenti stariji od } \\
55 \text { godina (A.S.) }\end{array}$ & T-test & Sig. (2-tailed) \\
\hline Očekivanja & 6,63 & 6,72 & 1,233 & 0,219 \\
\hline
\end{tabular}

Tablica 8. Rezultati t-testa za nezavisne uzorke - razlike u prosječnim ocjenama percepcije s obzirom na dob ispitanika

\begin{tabular}{|c|c|c|c|c|}
\hline ČESTICA & $\begin{array}{c}\text { Pacijenti } \\
\text { do } 55 \text { godina } \\
\text { (A.S.) }\end{array}$ & $\begin{array}{c}\text { Pacijenti stariji od } \\
55 \text { godina (A.S.) }\end{array}$ & T-test & Sig. (2-tailed) \\
\hline Percepcija & 6,31 & 6,55 & 2,536 & 0,012 \\
\hline Napomena: A.S. - aritmetička sredina, Sig.(2-tailed) - značajnost dvostranog testa. & & \\
\hline
\end{tabular}




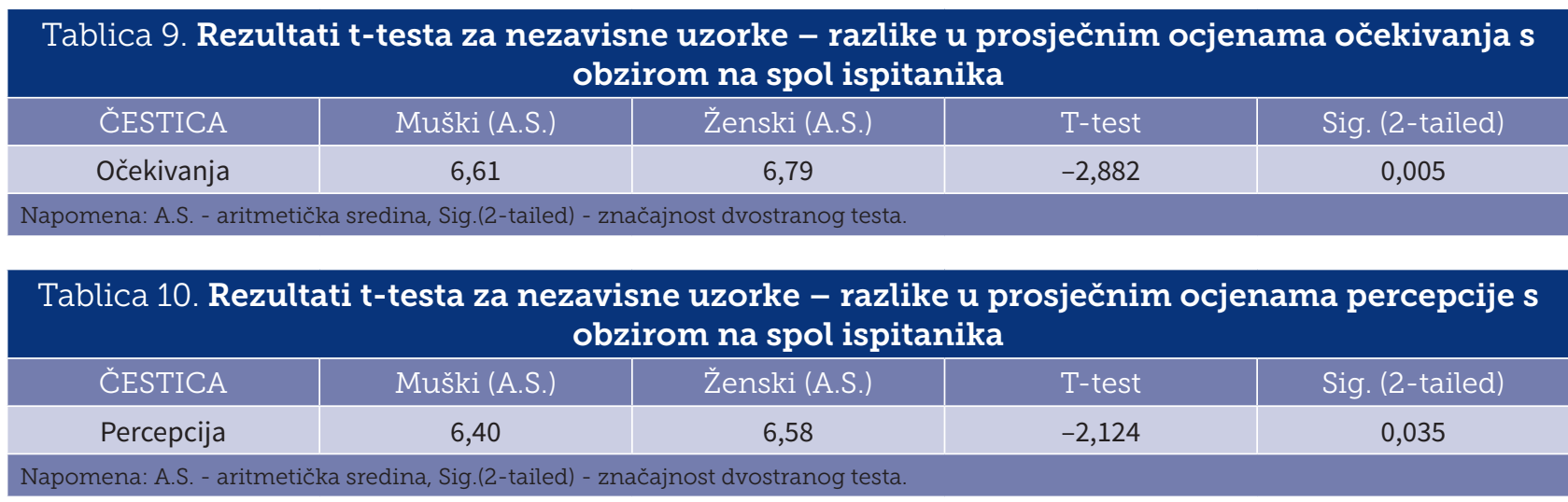

Primjenom t-testa provjerena je i razlika u percepciji kvalitete usluga između korisnika muškog i ženskog spola. Rezultati su prikazani u tablici 10 i može se uočiti da postoji statistički značajna razlika $(p<0,05)$ u prosječnim ocjenama između dvije skupine ispitanika.

Druga primijenjena metoda bivarijatne statističke analize bila je analiza varijance (engl. analysis of variance - ANOVA) kojom je uspoređena značajnost razlika u prosječnim ocjenama za očekivanu i percipiranu vrijednost s obzirom za razinu obrazovanja ispitanika te na vrstu korištene medicinske usluge.

Iz tablice 11 vidljivo je da Levenov test nije statistički značajan $(p>0,05)$ u pet slučajeva kada su u pitanju očekivane vrijednosti te da su varijance između promatranih skupina korisnika s obzirom na razinu obrazovanja u tim česticama jednake, odnosno homogene. Rezultati jednostavne analize varijance ukazali su na to da u 32 čestice ne postoji statistički značajna razlika u prosječnim ocjenama očekivane kvalitete usluga s obzirom na razinu obrazovanja.

Statistički značajna razlika u prosječnim ocjenama nađena je samo u čestici „ZU mora pružati klijentima individualiziranu pažnju", što znači da korisnici s različitom razinom obrazovanja očekuju različitu količinu pažnje u zdravstvenim ustanovama. S obzirom na to da za ostale čestice ne postoji statistički značajna razlika, može se zaključiti kako razina obrazovanja ne utječe na razliku prosječne ocjene očekivane kvalitete usluge.

U tablici 12 prikazani rezultati analize značajnosti razlike između prosječnih ocjena očekivane i percipirane vrijednosti s obzirom na vrstu korištene medicinske usluge.

Levenov test nije bio statistički značajan ( $p>0,05)$ u 19 čestica očekivane kvalitete usluga. Varijance između promatranih skupina korisnika s obzirom na vrstu ko- rištene medicinske usluge $u$ tim su česticama jednake, odnosno homogene.

Rezultati u tablici 12 upućuju na statistički značajnu razliku u prosječnim ocjenama 18 čestica očekivane kvalitete usluga s obzirom na vrstu korištene medicinske usluge. Riječ se o većini čestica iz promatranog koncepta te se može zaključiti kako u tim slučajevima vrsta korištene medicinske usluge znatno utječe na ocjenjivanje očekivane kvalitete usluga.

Za preostale čestice ne postoji statistički značajna razlika u prosječnim ocjenama očekivane kvalitete usluga s obzirom na korištenu medicinsku uslugu. Prema tome, korisnici koji se koriste različitim medicinskim uslugama imaju slična (a ne statistički različita) očekivanja kada su u pitanju oprema modernog izgleda, atraktivan izgled zgrada i prostorija, ugodan inventar i namještaj, čista i uredna zdravstvena ustanova, raspolaganje opremom i objektima u skladu s uslugama koje pruža ZU, laka dostupnost (parkiralište, dizala i sl.), pružanje usluge korektno već u prvom pokušaju, nalaženje vremena za odgovori na pitanje klijenta, pružanje individualne pažnje od strane ustanove i osoblja, brižljivo vođenje računa o interesima klijenata, razumijevanje specifičnih potreba klijenata, jednostavno snalaženje po ustanovi, ponuda različitih medicinskih programa i sportsko-rekreacijskih programa.

Nadalje, iz tablice 12 vidljivo je da Levenov test nije bio statistički značajan $(p>0,05)$ u 32 slučaja kada je u pitanju percipirana kvaliteta usluga te su varijance između promatranih skupina korisnika s obzirom na razinu obrazovanja u tim česticama jednake, odnosno homogene.

Rezultati jednostavne analize varijance ukazali su kako ne postoji statistički značajna razlika u prosječnim ocjenama čestica iz koncepta percipirane vrijednosti s obzirom na vrstu korištene medicinske usluge. Može se 


\section{Tablica 11. Analiza varijance za prosječne ocjene očekivanja i percepcije - čestica „razina obrazovanja”}

\begin{tabular}{|c|c|c|c|c|c|c|c|}
\hline & & OČEK & IVANJ & & PERC & EPCIJ & \\
\hline & Čestice (tvrdnje) & Sig. L. test & $\mathrm{F}$ & Sig. & Sig. L. Test & $\mathrm{F}$ & Sig. \\
\hline 1. & Moderna oprema & 0,003 & 1,236 & 0,298 & 0,163 & 1,213 & 0,307 \\
\hline 2. & Atraktivan izgled zgrada i prostorija & 0,010 & 1,579 & 0,196 & 0,076 & 1,750 & 0,159 \\
\hline 3. & Uredno osoblje & 0,055 & 0,569 & 0,636 & 0,000 & 2,293 & 0,080 \\
\hline 4. & Ugodan inventar i namještaj & 0,063 & 0,461 & 0,710 & 0,011 & 1,593 & 0,193 \\
\hline 5. & Čisti pribor i uređaji & 0,092 & 0,469 & 0,704 & 0,000 & 3,921 & 0,010 \\
\hline 6. & Čista i uredna zdravstvena ustanova & 0,274 & 0,332 & 0,802 & 0,003 & 0,874 & 0,456 \\
\hline 7. & $\begin{array}{c}\text { Raspolaganje opremom i objektima u skladu s uslugama koje } \\
\text { pruža ZU }\end{array}$ & 0,000 & 1,289 & 0,280 & 0,000 & 1,687 & 0,172 \\
\hline 8. & Laka dostupnost (parkiralište, dizala i sl.) & 0,008 & 0,916 & 0,434 & 0,305 & 0,138 & 0,937 \\
\hline 9. & Pravodobno izvršavanje obećanja & 0,023 & 0,754 & 0,521 & 0,000 & 2,753 & 0,044 \\
\hline 10. & Razumijevanje za probleme klijenata & 0,001 & 1,134 & 0,337 & 0,000 & 4,265 & 0,006 \\
\hline 11. & Pružanje usluge korektno već u prvom pokušaju & 0,000 & 1,703 & 0,168 & 0,000 & 2,919 & 0,036 \\
\hline 12. & Ustanova pruža usluge u obećanom vremenu & 0,027 & 0,716 & 0,543 & 0,000 & 3,210 & 0,024 \\
\hline 13. & Vođenje dokumentacije bez pogrešaka & 0,012 & 0,776 & 0,509 & 0,000 & 1,869 & 0,137 \\
\hline 14. & Obavještavanje klijenata o točnom vremenu pružanja usluge & 0,001 & 1,170 & 0,323 & 0,000 & 2,666 & 0,049 \\
\hline 15. & Osoblje pruža brze usluge & 0,000 & 1,530 & 0,208 & 0,000 & 2,205 & 0,089 \\
\hline 16. & Osoblje je spremno pomoći klijentima & 0,001 & 1,317 & 0,271 & 0,000 & 3,318 & 0,021 \\
\hline 17. & Osoblje nalazi vremena odgovoriti klijentu na pitanje & 0,003 & 0,776 & 0,509 & 0,000 & 4,584 & 0,004 \\
\hline 18. & Osoblje pruža usluge bez kašnjenja & 0,173 & 0,221 & 0,882 & 0,000 & 2,769 & 0,043 \\
\hline 19. & Ulijevanje povjerenja & 0,038 & 0,611 & 0,609 & 0,005 & 1,171 & 0,322 \\
\hline 20. & Osjećaj sigurnosti i bezbrižnosti & 0,029 & 0,534 & 0,660 & 0,001 & 1,192 & 0,314 \\
\hline 21. & Ljubazno osoblje & 0,002 & 1,035 & 0,378 & 0,000 & 2,084 & 0,104 \\
\hline 22. & Osoblje zna odgovoriti na pitanja klijenta & 0,000 & 1,738 & 0,161 & 0,000 & 1,734 & 0,162 \\
\hline 23. & Ustanova pruža individualnu pažnju & 0,000 & 3,251 & 0,023 & 0,001 & 1,626 & 0,185 \\
\hline 24. & Stručno pružanje usluga & 0,011 & 0,835 & 0,476 & 0,000 & 1,968 & 0,121 \\
\hline 25. & Osoblje pruža individualiziranu pažnju & 0,002 & 1,001 & 0,394 & 0,003 & 1,343 & 0,262 \\
\hline 26. & Brižljivo vođenje računa o interesima klijenata & 0,013 & 0,869 & 0,459 & 0,003 & 1,273 & 0,285 \\
\hline 27. & Razumijevanje specifičnih potreba klijenata & 0,000 & 1,964 & 0,121 & 0,000 & 3,347 & 0,020 \\
\hline 28. & Jednostavno snalaženje po ustanovi & 0,000 & 1,431 & 0,235 & 0,002 & 3,134 & 0,027 \\
\hline 29. & Informacije su dostupne, jednostavne i jasne & 0,000 & 1,280 & 0,283 & 0,000 & 4,207 & 0,007 \\
\hline 30. & Ponuda različitih medicinskih programa & 0,007 & 1,012 & 0,389 & 0,004 & 1,523 & 0,210 \\
\hline 31. & Ponuda različitih sportsko-rekreacijskih programa & 0,000 & 2,207 & 0,089 & 0,056 & 2,150 & 0,096 \\
\hline 32. & $\begin{array}{l}\text { Ponuda je prilagođena suvremenim trendovima i potrebama } \\
\text { klijenata }\end{array}$ & 0,006 & 0,894 & 0,445 & 0,016 & 1,603 & 0,190 \\
\hline 33. & Prepoznatljiv imidž & 0,000 & 1,978 & 0,119 & 0,007 & 1,131 & 0,338 \\
\hline
\end{tabular}




\section{Tablica 12. Analiza varijance za prosječne ocjene očekivanja i percepcije -} čestica "korištena medicinska usluga"

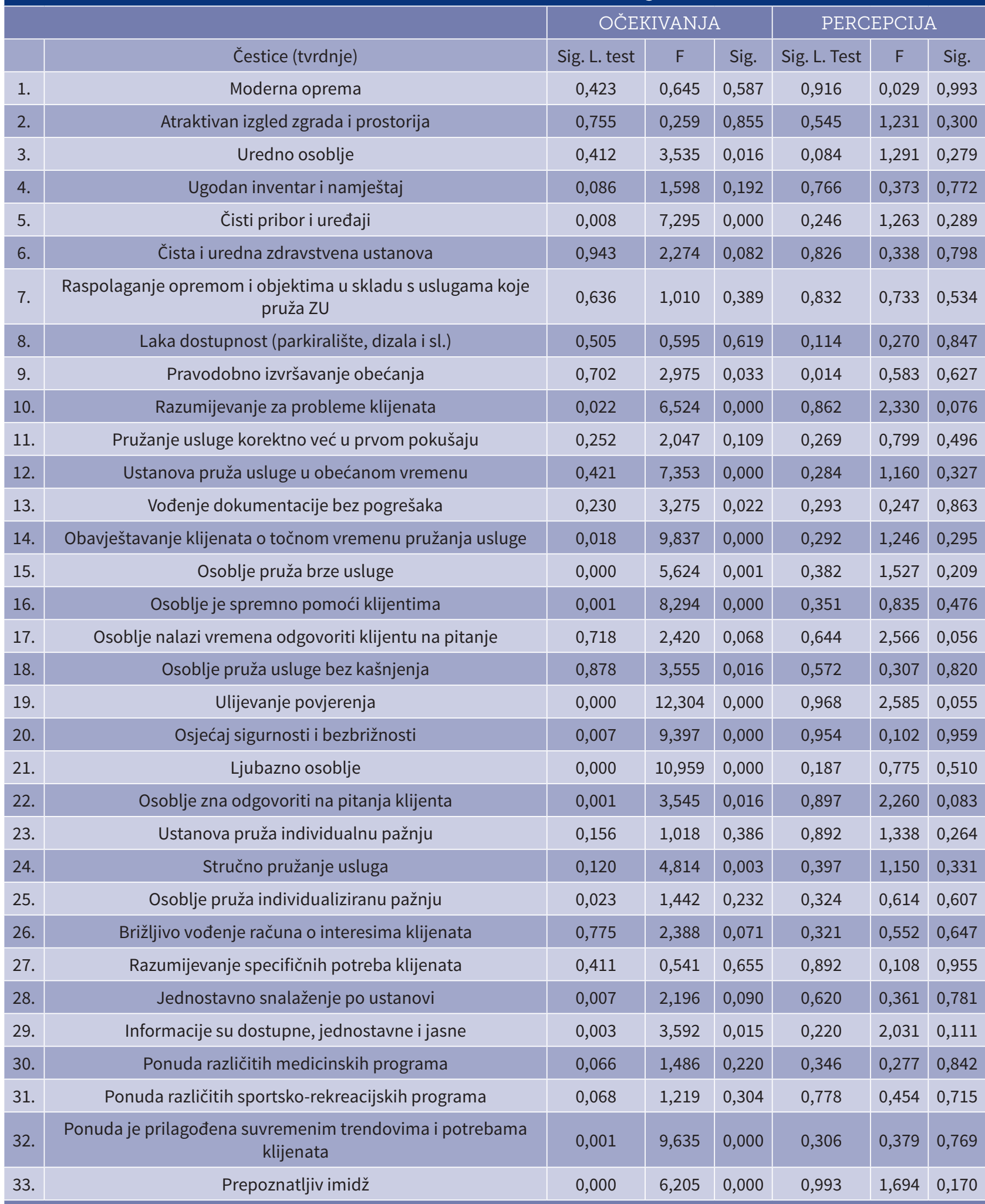

Napomena: Sig. Lev. test - pouzdanost Levenova testa; F - vrijednost ANOVA; Sig. - pouzdanost analize ANOVA; * - značajnost razlike na razini $p=0,05$. 
zaključiti kako su korisnici medicinskih usluga slično (a ne statistički različito) ocijenili kvalitetu usluga u Thalassotherapiji Opatija, bez obzira na vrstu medicinske usluge kojom su se koristili.

\section{Rasprava}

Empirijske su studije vezane za mjerenje kvalitete usluge u zdravstvenom turizmu rijetke. Ovo istraživanje može se smatrati jedinstvenim i pionirskim u Hrvatskoj posebice u segmentu SERVQUAL istraživanja u području specijalnih bolnica i zdravstvenog turizma i nastavak dosadašnjih istraživanja dijela grupe autora. Dimenzije su koje su mjerene ovim istraživanjem: opipljivost (oprema, prostor, odjeća osoblja i slično), pouzdanost, sigurnost, razumijevanje i odgovornost.

Na primjeru ove ustanove ljestvica očekivanja pokazala je da korisnici žele prije svega da zdravstvena usluga bude uredna i čista, a osobito se to odnosi na pribor i uređaje. Važno je i osoblje - od njega korisnici očekuju da bude stručno, da ulijeva povjerenje i da bude uredno. Ljestvica percepcije ukazuje da su, unatoč uskom negativnom jazu (raskoraku) u odnosu na očekivanja, najviše ocjene dobili upravo urednost i čistoća ustanove te pribora i uređaja, a među pet najbolje ocijenjenih tvrdnji i one su koje se odnose na osoblje - ponašanje osoblja ulijeva povjerenje, pacijenti se u Thalassotherapiji Opatija osjećaju sigurno i bezbrižno, a osoblje je stručno i, zahvaljujući svojem znanju, zna odgovoriti na pitanja korisnika.

Najmanja očekivanja korisnici su imali o atraktivnosti zgrade, modernom izgledu opreme, inventara i namještaja te ponudi sportsko-rekreacijskih i različitih medicinskih programa, što je i očekivano s obzirom na to da je riječ o korisnicima koji dolaze ciljano na preglede ili dijagnostičke pretrage i ne zadržavaju se dugo u ustanovi. No unatoč tome na ljestvici percepcije najmanje ocjene dobili su upravo opipljivi elementi - dostupnost Thalassotherapije Opatija i mogućnost snalaženja u ustanovi, a negativna je i percepcija atraktivnosti izgleda zgrade i prostorija, inventara i namještaja. Naime, iako na ljestvici očekivanja opipljivost nije visoko ocijenjena $(6,60)$, upravo su to elementi koji se najlakše zapažaju pa je jaz u ovoj dimenziji bio najveći $(-0,32)$. To je posebno važno u kontekstu činjenice da je potvrđena hipoteza da su najviša očekivanja u dimenzijama pouzdanosti i sigurnosti te da ustanova prilično ispunjava ta očekivanja jer je jaz u ovim dimenzijama bio manji nego kod opipljivih elementa.

Zanimljivo je da je među pet najlošije ocijenjenih bila tvrdnja o ponudi sportsko-rekreacijskih programa. lako ovi nemedicinski elementi nisu bili u središtu pozornosti ispitivanih korisnika, upravo su njih percipirali negativno.

Najmanji jaz bio je kod razumijevanja $(-0,11)$ i sigurnosti $(-0,13)$ te odgovornosti $(-0,17)$, što znači da su korisnici, iako je jaz, doduše, uzak, ali ipak negativan, evidentno dobili očekivanu uslugu i kod tih se dimenzija percepcija najviše približila očekivanjima. Visoke ocjene dobila je i ljubaznost osoblja pa je odbačena hipoteza da korisnici usluga percipiraju nedostatak ljubaznosti, a nije potvrđena ni hipoteza da percipiraju nedostatak želje za pomaganjem i osiguravanjem brze usluge. Ukupni imidž ustanove na višoj je razini od očekivanja, a korisnici usluga zadovoljni su i individualiziranom pažnjom, i ustanove u cjelini i osoblja. Općenito, dakle, ispitanici su bili zadovoljni ukupnim primljenim uslugama (prosječna ocjena 6,65 od maksimalnih 7) i boravkom te imaju povjerenje u ustanovu. Vrlo je visoko ocijenjena i tvrdnja da je zdravstvena usluga premašila očekivanja - ocjena je 6,28, a najveća je moguća 7. Dakle, korisnici su Thalassotherapiju Opatija prepoznali kao kvalitetnu ustanovu koju će preporučiti drugima (prosječna ocjena tvrdnje 6,65$)$, a i sami će se ponovno koristiti njezinim uslugama $(6,74)$.

Usporedimo li dobivene rezultati empirijskoga istraživanja s postavljenim hipotezama, rezultati su pokazali da možemo potvrditi glavnu hipotezu da postoji znatno odstupanje između percepcije i očekivanja kvalitete zdravstvenih usluga. Naime, prosječna ocjena očekivanja na ljestvici od sedam stupnjeva iznosila je 6,69, dok je prosječna ocjena na ljestvici percepcije bila 6,48. Iz navedenoga je bio utvrđen negativni SERVQUAL jaz od $-0,21$ između ocjena percepcije i očekivanja. Provođenjem t-testa za zavisne uzorke došlo se do zaključka da je u većini ocjenjivanih elemenata usluge bila riječ o statistički značajnoj razlici. Rezultati su pokazali da su od 33 ocijenjene tvrdnje u njih 23 razine pouzdanosti manje od 0,05 te se može zaključiti da su navedene razlike statistički značajne. Tvrdnje ,atraktivan izgled zgrada i prostorija”, „osoblje pruža usluge bez kašnjenja”, „osjećaj sigurnosti i bezbrižnosti”, „osoblje zna odgovoriti na pitanja klijenata”, „ustanova pruža individualiziranu pažnju”, „osoblje pruža individualiziranu pažnju”, „razumijevanje specifičnih potreba klijenata”, „ustanova nudi različite medicinske programe”, „usta- 
nova nudi različite sportsko-rekreacijske programe" i „ustanova ima prepoznatljiv imidž" imaju razinu pouzdanosti veću od 0,05 . U tim slučajevima ne postoji značajna razlika između prosječnih ocjena za očekivanje i percepciju. S obzirom na to da u većini tvrdnji postoji statistički značajno odstupanje između prosječne ocjene za percepciju i očekivanje korisnika zdravstvenih usluga, prihvaćena je glavna hipoteza $H 1$ da postoje značajna odstupanja između percepcija i očekivanja korisnika zdravstvenih usluga.

Rezultati su pokazali da su najviše prosječne ocjene očekivanja po dimenzijama imale dimenzija sigurnosti $(6,81)$ i dimenzija pouzdanosti $(6,77)$ pa se mogla prihvatiti pomoćna hipoteza $\mathrm{H} 2$ da korisnici zdravstvenih usluga imaju najviša očekivanja u dimenzijama pouzdanosti i sigurnosti.

Ljubaznost osoblja ispitivala se kroz tvrdnju „Osoblje u TTO-u uvijek je ljubazno prema klijentima." S obzirom na to da su ispitani korisnici vrlo visokom prosječnom ocjenom ocijenili ljubaznost osoblja (A.S. $=6,66)$ te je SERVQUAL jaz uzak i iznosi -0,14, moglo se zaključiti da korisnici ne percipiraju nedostatak ljubaznosti zaposlenika i odbaciti pomoćnu hipotezu H3 da korisnici percipiraju nedostatak ljubaznosti zaposlenika u zdravstvenim ustanovama.

Želja zaposlenika za pomaganjem korisnicima i osiguranjem brze usluge ispitivala se kroz pet tvrdnji: „Osoblje TTO-a obavještava klijente o točnom vremenu kada će neka usluga biti pružena”, „Osoblje TTO-a pruža klijentima brzu uslugu”, „Osoblje TTO-a uvijek je spremno pomoći klijentu”, „Osoblje TTO-a uvijek nalazi vremena odgovoriti klijentu na pitanje” i „Osoblje TTO pruža usluge u točno obećanom vremenu (bez kašnjenja)". Srednja prosječna ocjena percepcije promatranih tvrdnji iznosila je visokih 6,57 s uskim SERVQUAL jazom od $-0,16$, iz čega se može zaključiti da su korisnici zadovoljni načinom na koji zaposlenici pružaju usluge te se moglo odbaciti hipotezu H4 da korisnici percipiraju nedostatak želje zaposlenika u zdravstvenim ustanovama za pomaganjem korisnicima i osiguranjem brze usluge.

Kako bi se provjerila peta hipoteza da postoji statistički značajna razlika između očekivanja klijenata s obzirom na dob ispitanika, primijenjena je metoda t-testa za nezavisne uzorke (engl. independent samples t-test). Rezultati t-testa za nezavisne uzorke pokazali su da stariji korisnici zdravstvenih usluga imaju viša očekivanja od mlađih korisnika. Međutim, razlike u prosječnim ocjenama nisu statistički značajne $(p>0,05)$ pa se hipoteza H5 da postoji statistički značajna razlika u prosječnim ocjenama za očekivanu vrijednost s obzirom na dob korisnika mogla odbaciti.

Nakon što nije potvrđeno da postoji statistički značajna razlika u očekivanjima s obzirom na dob korisnika, izvršena je provjera razlike u prosječnim ocjenama korisnika na ljestvici percepcije s obzirom na dob korisnika. Primjenom t-testa za nezavisne uzorke uspoređene su ocjene percepcije u ranije definiranim dobnim skupinama. Rezultati su pokazali da su prosječne ocjene percepcije više kod starijih korisnika u odnosu na mlađe korisnike. Budući da razlika prosječnih ocjena na ljestvici percepcije iznosi 0,24 i statistički je značajna $(p<0,05)$, mogla se prihvatiti šesta hipoteza H6 da postoji statistički značajna razlika u prosječnim ocjenama za percipiranu vrijednost s obzirom na dob korisnika.

U ispitivanom uzorku korisnika zdravstvenih usluga bilo je više muškaraca, njih 99 ili 55,6 \%. Žena je u ispitivanom uzorku bilo 79 , odnosno $44,4 \%$. Pretpostavljeno je kako nema razlike u očekivanjima kvalitete usluga s obzirom na spol korisnika. Rezultati usporedbe prosječnih ocjena očekivanja između korisnika različitoga spola pokazali su da postoji razlika u ocjenama te da je ta razlika statistički značajna $(p<0,05)$. Naime, žene su imale višu prosječnu ocjenu očekivanja od muškaraca te se mogla odbaciti hipoteza $\mathrm{H} 7$ da ne postoji statistički značajna razlika u prosječnim ocjenama za očekivanu vrijednost s obzirom na spol korisnika.

Primjenom t-testa provjerena je i razlika u percepciji kvalitete usluga između ispitanika muškog i ženskog spola. Rezultati usporedbe ocjena percepcije između korisnika muškoga i ženskoga spola pokazali su da postoji statistički značajna razlika $(p<0,05)$ u prosječnim ocjenama između dvije skupine korisnika te se stoga mogla odbaciti hipoteza H8 da ne postoji statistički značajna razlika u prosječnim ocjenama za percipiranu vrijednost s obzirom na spol korisnika.

Konačno, statistički značajna razlika u prosječnim ocjenama nađena je samo u čestici „ZU mora pružati klijentima individualiziranu pažnju", što znači da korisnici s različitom razinom obrazovanja očekuju različitu količinu pažnje u zdravstvenim ustanovama. S obzirom na to da za ostale čestice ne postoji statistički značajna razlika, moglo se zaključiti kako razina obrazovanja ne utječe na razliku prosječne ocjene očekivane kvalitete usluge te se moglo odbaciti hipotezu H9 da postoji statistički značajna razlika u prosječnim ocjenama za očekivanu vrijednost s obzirom na razinu obrazovanja korisnika.

Korisnici medicinskih usluga različite razine obrazovanja različito su ocjenjivali čistoću pribora i uređaja, 
pravodobno izvršavanje obećanja, razumijevanje za probleme klijenata, pružanje usluge korektno već u prvom pokušaju, pružanje usluge u obećanom vremenu, obavještavanje klijenata o točnom vremenu pružanja usluge, spremnost osoblja da pomogne klijentima, nalaženje vremena za odgovor na pitanje klijenta, pruža usluge bez kašnjenja, razumijevanje specifičnih potreba klijenata, jednostavno snalaženje po ustanovi te dostupne, jednostavne i jasne informacije. Iz svega navedenog možemo zaključiti da se hipoteza H10 da postoji statistički značajna razlika u prosječnim ocjenama za percipiranu vrijednost s obzirom na razinu obrazovanja ispitanika mogla djelomično prihvatiti.

Korisnici koji se koriste različitim medicinskim uslugama imaju slična (a ne statistički različita) očekivanja kada su u pitanju oprema modernog izgleda, atraktivan izgled zgrada i prostorija, ugodan inventar i namještaj, čista i uredna zdravstvena ustanova, raspolaganje opremom i objektima u skladu s uslugama koje pruža ZU, laka dostupnost (parkiralište, dizala i sl.), pružanje usluge korektno već u prvom pokušaju, nalaženje vremena za odgovor na pitanje klijenta, pružanje individualne pažnje od strane ustanove i osoblja, brižljivo vođenje računa o interesima klijenata, razumijevanje specifičnih potreba klijenata, jednostavno snalaženje po ustanovi te ponuda različitih medicinskih programa i sportskorekreacijskih programa. Rezultati jednostavne analize varijance ukazuju kako ne postoji statistički značajna razlika u prosječnim ocjenama čestica iz koncepta percipirane vrijednosti s obzirom na vrstu korištene medicinske usluge. Može se zaključiti kako korisnici medicinskih usluga slično (a ne statistički različito) ocjenjuju kvalitetu usluga u Thalassotherapiji Opatija, bez obzira na vrstu medicinske usluge kojom su se koristili. Slijedom navedenog, hipoteza $\mathrm{H} 11$ da ne postoji statistički značajna razlika u prosječnim ocjenama za očekivanu $i$ percipiranu vrijednost s obzirom na vrstu korištene medicinske usluge mogla se djelomično prihvatiti s obzirom na različite rezultate dobivene za očekivanu i percipiranu vrijednost.

Rezultati ovoga istraživanja mogu se usporediti s istraživanjem Marković i suradnika provedenom u ostalim hrvatskim specijalnim bolnicama. Ovo je istraživanje pokazalo da je većina ispitanika imala visoka očekivanja kvalitete usluga u Thalassotherapiji Opatija, a relativno su visoke i ocjene percepcije kvalitete. lako su očekivanja nešto veća od percepcije, SERVQUAL jaz znatno je manji nego što je bio u istraživanju provedenom 2003. godine. U istraživanju iz 2003. godine prosječne ocjene očekivanja i percepcije bile su niže. Prosječna ocje- na očekivanja bila je 6,35 , dok je u ovome istraživanju prosječna ocjena istraživanja 6,69. Prosječna ocjena percepcije u ranijem istraživanju bila je 5,00, a u ovome iznosi 6,48. SERVQUAL jaz u istraživanju iz 2003. godine iznosio je 1,35, dok je u ovom istraživanju 0,21. Dakle, povećala su se i očekivanja korisnika usluga, ali i njihova percepcija kvalitete usluga pa je i SERVQUAL jaz znatno smanjen, odnosno smanjen je raskorak između očekivanja i percepcije. Rezultat je to promjena na čelu poslovodstva ustanove, budući da je uprava koja vodi bolnicu unazad nekoliko godina politiku kvalitete prepoznala kao jedno od najvažnijih pitanja, uz dokazanu predanost implementaciji sugestija koje donose empirijska istraživanja.

Budući da je i ovo istraživanje pokazalo pozitivan raskorak (jaz) samo kada je riječ o prepoznatljivosti imidža, odnosno percipirani imidž Thalassotherapije Opatija veći je od očekivanoga, uprava je neposredno po predočavanju rezultata istraživanja poduzela pozitivne korake kojima su riješeni problem parkirališnih mjesta ispred ustanove te jasno označavanje prostora unutar ustanove uz jasne upute korisnicima. Upravo promjene u praksi potvrdile su uspješnost aplikativnog cilja istraživanja.

Za razliku od našega istraživanja koje je provedeno u Hrvatskoj, Snoj i Mumel (2002) mjerili su percipiranu kvalitetu usluge u slovenskim lječilištima, dok su Gonzáles Comesana i Brea (2007) procjenjivali percipiranu kvalitetu usluge u španjolskim termama. Rad je sa suradnicima istraživao međuovisnost kvalitete medicinskih usluga i zadovoljstva pacijenata u medicinskom turizmu. Istraživanje je provedeno u Maleziji (Rad i sur. 2010). Primijenjen je model SERVQUAL i, kao i u našem istraživanju, utvrđena je pozitivna povezanost između kvalitete usluga i zadovoljstva pacijenata. Povezanost dimenzije opipljivosti sa zadovoljstvom, za razliku od našeg istraživanja, nije potvrđena.

Guiry i Vequis (2011) istraživali su očekivanja i percepcije kvalitete usluga na uzorku turista koji su putovali izvan Sjedinjenih Američkih Država kako bi konzumirali određene medicinske usluge. $U$ usporedbi s ovim istraživanjem, njihovo istraživanje pokazalo je da postoji znatna razlika između njihovih očekivanja i percepcije kvalitete usluge u čak četiri od pet dimenzija kvalitete usluge, a najveći je raskorak kada je riječ o pouzdanosti. Za razliku od našeg istraživanja, jedina dimenzija gdje su se poklopila očekivanja i percepcija povezana je s odzivom na zahtjeve klijenata.

Primjenom modela SERVQUAL Quintela, Correia i Antunes istražili su utjecaj kvalitete usluga na zadovoljstvo 
klijenata u zdravstvenom turizmu u Portugalu. Utvrdili su tri kvalitete usluge i dokazali da na zadovoljstvo korisnika portugalskih termalnih izvora najviše utječu sposobnost zaposlenika da djeluju pouzdano i točno, njihova volja da pomognu klijentima i pruže promptnu uslugu i individualiziranu pažnju, što je sukladno i našem istraživanju.

Awaad (2012) je istraživanjem u lječilišnim centrima u Maleziji dokazao utjecaj kvalitete usluge na zadovoljstvo i ponavljanje kupnje. Njegovo istraživanje, za razliku od našeg, pokazalo je da na zadovoljstvo najviše utječu opipljivost i suosjećajnost, zatim pouzdanost i odgovornost, dok povezanost sigurnosti i zadovoljstva nije utvrđena.

Istraživanja u Hrvatskoj vrlo su rijetka. Jedno od malobrojnih istraživanja mjerenja kvalitete zdravstvenih usluga u Hrvatskoj proveli su Bajto i Kondić (2006) na uzorku korisnika usluga Opće županijske bolnice u Našicama. Utvrdili su da se model SERVQUAL uspješno može primijeniti u zdravstvenim institucijama te da dovodi do objektivnih pokazatelja zadovoljstva korisnika usluga na osnovi kojih se mogu poduzeti konkretne aktivnosti za njihovo poboljšanje.

Mečev i Goleš Kardum (2015) u svojem su istraživanju ispitivali pacijentovu percepciju kvalitete primarne zdravstvene zaštite, odnosno postoji li razlika između pacijentova očekivanja i razine zadovoljstva dobivenom medicinskom uslugom. Utvrdili su postojanje jaza u svim dimenzijama te da nema razlike u percepciji kvalitete usluga s obzirom na dob i spol pacijenta, no da postoji značajna razlika u razini zadovoljstva ovisno o statusu zaposlenosti i učestalosti korištenja uslugama.

Ozretić Došen i suradnici (2000) u svojem radu iznose rezultate provedenog istraživanja o kvaliteti zdravstvenih usluga pruženih u ustanovama primarne zdravstvene zaštite primjenom instrumenta SERVQUAL. Rezultati su pokazali da postoji znatan jaz između percepcija i očekivanja korisnika usluga te da je jaz različit ovisno o dimenzijama. Najveći jaz zabilježen je kod dimenzija „odgovornost”, „sigurnost” i ,pouzdanost”.

Marković i sur. (2015) uz pomoć modela SERVQUAL mjerili su kvalitetu usluga u hrvatskom wellness-turizmu i utvrdili su da klijenti imaju visoka očekivanja posebno u pogledu pouzdanosti usluga i kvalitete osoblja, suosjećanja i izgleda prostora i osoblja, a ti su rezultati sukladni i saznanjima dobivenima ovim istraživanjem. Konačno, Marković, Lončarić i Lončarić objavili su 2014. godine rezultate mjerenja kvalitete usluga u specijalnim bolnicama za medicinsku rehabilitaciju u Repu- blici Hrvatskoj primjenom modela SERVQUAL kojim su potvrdili prikladnost modela SERVQUAL za mjerenje kvalitete zdravstvenih usluga, a najveći jaz ostvaren je u području nemedicinskih usluga. Zanimljivo je da je to istraživanje također dokazalo i povezanost zadovoljstva pacijenata uslugama bolnica i njihove lojalnosti, što je bio slučaj i u ovom istraživanju.

Ograničenja provedenoga empirijskog istraživanja odnose se prije svega na uzorak i metode provedenoga istraživanja. lako se nastojalo obuhvatiti što veći broj korisnika kako bi se postigla reprezentativnost uzorka, njime je obuhvaćen tek dio korisnika usluga ove ustanove, i to uglavnom onih koji dolaze na kraće vrijeme i ciljano na određeni pregled ili pretragu, što bi moglo biti jedno od ograničenja istraživanja. $U$ istraživanje je uključen manji postotak stacionarnih pacijenata koji u ustanovi borave duže vrijeme i imaju veće zahtjeve kada je riječ o različitim elementima ponude. Osim toga, visok je postotak onih koji su došli zbog korištenja medicinskim uslugama kardiologije, a vrlo mali broj ispitanika došao je zbog ostalih usluga koje čine znatnu ponudu ove zdravstvene ustanove, kao što su fizikalna medicina i reumatologija, dermatologija, neurologija, radiologija, dijetoterapija i sportska medicina. Istraživanje je, nadalje, bilo vremenski ograničeno $i$ ispitivani su korisnici koji su u to vrijeme boravili u ustanovi pa istraživači nisu mogli u potpunosti utjecati na odabir korisnika uključenih u ispitivanje zbog vremenskog i prostornog ograničenja.

Kako bi se u budućim istraživanjima omogućilo jasnije i preciznije razdvajanje medicinskih i nemedicinskih usluga i dobile konkretnije smjernice što učiniti kako bi ustanova dodatno ojačala i zadržala svoju poziciju lidera na zdravstveno-turističkom tržištu, potrebno je proširiti istraživanje primjenom alternativnih mjernih instrumenta (Parasuraman i sur. 1994), i to za stacionarne pacijente primjenom modela LODGSERV razvijenog za mjerenje kvalitete usluga smještaja (Knutson i sur. 1991; Getty i sur. 1994). Također, primjenom drugih metoda (analiza izgubljenih klijenata, tehnika kritičnih točaka, fokusne skupine ili dubinski intervju) moguće je dobiti još dublji uvid u eventualno postojanje elemenata usluge koje bi trebalo prilagođavati novonastalim zahtjevima i potrebama korisnika.

Budući da za procjenu kvalitete zdravstvenih usluga nije dovoljna samo ocjena korisnika, koji kvalitetu pružene usluge najčešće ocjenjuju samo po ishodu, istraživanjem kvalitete usluga u ustanovi trebalo bi obuhvatiti i stručnjake, zdravstvene djelatnike koji pruženu uslugu mogu ocijeniti i s gledišta profesionalnih potreba, a va- 
žan je segment u ukupnoj ocjeni kvalitete zdravstvene usluge i ocjena racionalnosti korištenja resursima.

Međutim, ovo je istraživanje nedvojbeno još jednom potvrdilo da je koncept kvalitete zdravstvenih usluga višedimenzionalan te da je uz primjenu modela SERVQUAL moguće na jednostavan i učinkovit način saznati očekivanja, potrebe i želje korisnika zdravstvenih ustanova, kao i njihove stavove o dobivenim uslugama, a zatim ih iskoristiti u svrhu kreiranja kvalitetne ponude.

\section{Zaključak}

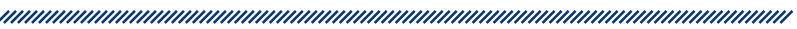

Koncept kvalitete zdravstvenih usluga istražuje se već više od dva desetljeća, ali u znanstvenoj i stručnoj praksi u RH još uvijek postoji mali broj radova u kojima se istražuje i mjeri razina zadovoljstva korisnika zdravstvenih usluga. Nužno je stvoriti odgovarajuću i znanstveno provjerenu sliku o potrebama, očekivanjima, percepcijama i zadovoljstvu, da bi se zdravstvena politika počela mijenjati u korist korisnika zdravstvenih usluga. Rezultati empirijskoga istraživanja zadovoljstva korisnika zdravstvenim uslugama provedenog u Specijalnoj bolnici za medicinsku rehabilitaciju bolesti srca, pluća i reumatizma Thalassotherapia Opatija pokazali su da je kvaliteta zdravstvenih usluga višedimenzionalan koncept. Primjena modela SERVQUAL pokazala se primjerenom za mjerenje kvalitete usluga u zdravstvenim ustanovama te je pokazano da postoji znatno odstupanje između percepcije i očekivanja kvalitete zdravstvenih usluga. Prosječna ocjena očekivanja na ljestvici od sedam stupnjeva iznosila je 6,69, dok je prosječna ocjena na ljestvici percepcije bila 6,48 uz negativan SERVQUAL jaz od -0,21 između ocjena percepcije i očekivanja. Međutim, treba voditi računa o tome da je najveći dio korisnika obuhvaćenih istraživanjem u Thalassotherapiji Opatija bio starije životne dobi, u mirovini i srednjoškolskog obrazovanja. Njihova očekivanja bila su vrlo visoka. Visokim ocjenama ukupno je ocijenjena i percepcija pruženih usluga, no jaz između očekivanja i percepcije bio je negativan, osim kada je riječ o imidžu ustanove. Istraživanje je pokazalo da najveća očekivanja korisnici imaju kada je riječ o pouzdanosti i sigurnosti, a najmanja kada je riječ o opipljivim elementima, odnosno fizičkoj dimenziji usluga. U tim najvažnijim dimenzijama (pouzdanost, sigurnost, razumijevanje, odgovornost) jaz je manji nego kada je riječ o opipljivim elementima. Kori- snici nisu uočili ni nedostatak ljubaznosti zaposlenika ni nedostatak njihove želje da im pomognu i osiguraju brzu uslugu. Zbog toga se može zaključiti da je ukupna ocjena kvalitete usluga u Thalassotherapiji Opatija, unatoč statistički značajnom negativnom jazu, vrlo dobra. To potvrđuje i rezultat da ju je većina korisnika prepoznala kao kvalitetnu ustanovu čijim će se uslugama i sami ponovno koristiti i preporučiti drugima.

\section{Referencije (APA)}

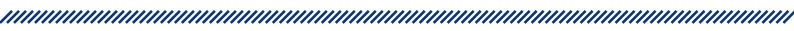

1. Lohr KN, Schroeder SA. A strategy for quality assurance in Medicare. New England Journal of Medicine; 1990, 322(10), 707-712.

2. Øvretveit J. A comparison of approaches to health service quality in the UK, USA \& Sweden and of the use of organizational audit frameworks. The European Journal of Public Health; 1994, 4(1), 46-54.

3. IOM. Medicare: a strategy for quality assurance (Vol. 1). National Academies Press; 1990.

4. Woodward CA, Svjetska zdravstvena organizacija. Strategies for assisting health workers to modify and improve skills: developing quality health care: a process of change; 2000.

5. Stavljenić-Rukavina A. Kvaliteta zdravstvene skrbi. Liječnički vjesnik; 2008, 130, 306-310.

6. Grönroos C. A service quality model and its marketing implications. European Journal of marketing; 1984, 18(4), 36-44.

7. Kotler P, Keller K, Martinović M. Upravljanje marketingom, 14. izdanje, Zagreb: Mate i Zagrebačka škola ekonomije i menadžmenta; 2014.

8. Stavljenić-Rukavina A, Kalanj K. Mjere za poboljšanje kvalitete zdravstvene skrbi, MEDIX; 2014, 14(86), 32-36.

9. Parasuraman A, Zeithaml VA, Berry LL. A conceptual model of service quality and its implications for future research. The Journal of Marketing; 1985, 41-50.

10. Parasuraman A, Berry L, Zeithaml V. Refinement and reassessment of the SERVQUAL scale. Journal of retailing; 2002, 67(4), 114.

11. Parasuraman A, Zeithaml VA, Berry, LL. Servqual: A multiple-item scale for measuring consumer perc. Journal of retailing; 1988, 64(1), 12.

12. Parasuraman A, Berry LL, Zeithaml VA. More on improving service quality measurement. Journal of retailing; 1993, 69(1), 140-147.

13. Marković $S$, Lončarić $D$, Lončarić $D$. Service quality and customer satisfaction in the health care industry - Towards health tourism market. Tourism and hospitality management; 2014, 20(2), 155-170. 
14. Babakus E, Mangold WG. Adapting the SERVQUAL scale to hospital services: an empirical investigation. Health services research; 1992, 26(6), 767.

15. Sadiq Sohail M. Service quality in hospitals: more favourable than you might think. Managing Service Quality: An International Journal; 2003, 13(3), 197-206.

16. Lam SS. SERVQUAL: A tool for measuring patients' opinions of hospital service quality in Hong Kong. Total Quality Management; 1997, 8(4), 145-152.

17. Zarei E, Daneshkohan A, Pouragha B, Marzban S, Arab M. An Empirical study of the Impact of Service Quality on patient Satisfaction in private Hospitals, Iran. Global journal of health science; 2015, 7(1), 1.

18. Yesilada F, Direktör E. Health care service quality: A comparison of public and private hospitals. African Journal of business management; 2010, 4(6), 962-971.

19. Ramsaran-Fowdar RR. Developing a service quality questionnaire for the hotel industry in Mauritius. Journal of Vacation Marketing; 2007, 13(1), 19-27.

20. Lei P, Jolibert A. A three-model comparison of the relationship between quality, satisfaction and loyalty: an empirical study of the Chinese healthcare system. BMC Health Services Research; 2012, 12(1), 436-447.

21. Rahman MR, Kutubi SS. Assessment of service quality dimensions in healthcare industry. A study on patient's satisfaction with Bangladeshi Private Hospitals. International Journal of Business and Management Invention; 2013, 2(4), 59-67.

22. Krishnamoorthy V, Srinivasan R. Measuring Patient's Perceived Service Quality For Multispeciality Hospital, RJCBS; 2014, (3), 59-69.

23. Peprah AA, Atarah BA. Assessing patient's satisfaction using SERVQUAL model: A case of Sunyani Regional Hospital, Ghana. International Journal of Business and Social Research; 2014, 4(2), 133-143.

24. Lee SM, Lee D, Kang CY. The impact of high-performance work systems in the health-care industry: employee reactions, service quality, customer satisfaction, and customer loyalty. The Service Industries Journal; 2012, 32(1), 17-36.

25. Pakdil F, Harwood TN. Patient satisfaction in a preoperative assessment clinic: an analysis using SERVQUAL dimensions. Total Quality Management \& Business Excellence; 2005, 16(1), 15-30.

26. Karassavidou E, Glaveli N, Papadopoulos CT. Quality in NHS hospitals: no one knows better than patients. Measuring Business Excellence; 2009, 13(1), 34-46.

27. Phillips PA, Petrovici DA. Conceptualising the Perceived Performance in Hospital Services: A Patient's Perspective; 2009.

28. Marković S. An Application of the Multivariate Statistical Analysis to Service Quality Measurement in Higher Education. Tourism and hospitality management; 2003, 9(1), 93-112.
29. Snoj B, Mumel D. The measurement of perceived differences in service quality - The case of health spas in Slovenia. Journal of vacation marketing; 2002, 8(4), 362-379.

30. González MEA, Comesaña LR, Brea JAF. Assessing tourist behavioral intentions through perceived service quality and customer satisfaction. Journal of business research; 2007, 60(2), 153-160.

31. Rad NF, Som APM, Zainuddin Y. Service quality and patients' satisfaction in medical tourism. World Applied Sciences Journal; 2010, 10(1), 24-30.

32. Guiry M, Vequist DG. Traveling abroad for medical care: US medical tourists' expectations and perceptions of service quality. Health Marketing Quarterly; 2011, 28(3), 253-269.

33. Quintela JA, Correia AG, Antunes JG. Service quality in health and wellness tourism - trends in Portugal. International Journal of Business, Management and Social Sciences; 2011, 2(3), 1-8.

34. Awad BAAAG. The relationships between service quality, satisfaction, and behavioral intentions of Malaysian spa center customers. International Journal of Business and Social Science; 2012, 3(1), 198-206.

35. Bajto M, Kondić Ž. Mjerenje zadovoljstva korisnika usluge SERVQUAL modelom na primjeru opće bolnice; 2005. Dostupno na: http://issuu.com/kvaliteta.net/docs/ bajto_m_rad (pristupljeno 7.1.2018.).

36. Mečev D, Kardum Goleš I. Primary healthcare service quality measurement: SERVQUAL Scale. Ekonomski vjesnik: Review of Contemporary Entrepreneurship, Business, and Economic Issues; 2015, 28(1), 161-177.

37. Škare T, Škare V, Ozretić Došen Đ. Mjerenje kvalitete usluge primarne zdravstvene zaštite SERVQUAL instrumentom. Revija za socijalnu politiku; 2010, 17(1), 27-44.

38. Marković S, Raspor S, Komšić J. Mjerenje kvalitete usluga wellnessa: case study. U: Drljača M (ur.): Zbornik radova 13. međunarodnog simpozija o kvaliteti „Kvaliteta i društvena odgovornost”, Hrvatsko društvo menadžera kvalitete, Solin, Hrvatska, 15. i 16.3.2012., 571-584.

39. Parasuraman A, ZeithamI VA, Berry LL. Alternative scales for measuring service quality: a comparative assessment based on psychometric and diagnostic criteria. U: Handbuch Dienstleistungsmanagement. Wiesbaden: Gabler Verlag; 1998, 449-482.

40. Knutson B, Stevens P, Wullaert C, Patton M, Yokoyama F. LODGSERV: A service quality index for the lodging industry. Hospitality Research Journal; 2010, 14(2), 277-284.

41. Getty JM, Thompson KN. A procedure for scaling perceptions of lodging quality. Hospitality Research Journal; 1994, 18, 75-75. 


\section{INVESTIGATING THE DIFFERENCE BETWEEN THE PERCEPTION AND EXPECTATIONS OF HEALTH SERVICE USERS USING THE SERVQUAL MODEL}

\section{Abstract

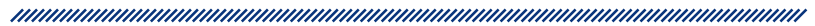

Introduction: The quality of health care services is increasingly becoming the subject of different studies. A special place in such studies is taken by the measurement of the quality of health services, and by defining their perception from the users' perspective.

Objective and methods: By applying an adjusted SERVQUAL model, the expectations and perceptions of 178 health service users in Thalassotherapy Opatija were investigated.

Results: Suitability of the SERVQUAL model for measuring the quality of health services has been verified. It has been found out that there is a significant gap between perception and expectation of service users. The highest gap was recorded when evaluating tangibility, i.e. physical elements of service delivery, while the lowest level was recorded when evaluating understanding $(-0.11)$, security $(-0.13)$ and responsibility $(-0.17)$, which still means that the users have nevertheless received the expected service. They were satisfied with the total number of services received (6.65) and their stay as well, and it was also found out that they have confidence in the institution. On the other hand the health care services exceeded the expectations (6.28). The users tend to recommend the institution to others (6.65) and to use its services by themselves again (6.74). The results showed that female users have higher expectations than males, and that they have a better perception of the quality of provided services. The older users have better perception of provided services than the young- er ones. When compared to the others, the users with a higher level of education show in terms of statistics higher expectations - they expect the staff to take some time to answer their questions, to understand their specific needs, and they also expect accuracy in service delivery. When it comes to perceived quality of service, there is no statistically significant difference with regard to the type of medical service used, so a conclusion can be made that the quality evaluation of the services provided by Thalassotherapy Opatija is similar, regardless the type of services used.

Conclusion: It has been confirmed that the concept of the quality of health services is multidimensional and that the application of the SERVQUAL model makes possible to identify the users' expectations, needs and wants efficiently, as well as their attitudes towards the services obtained and then consequently to use them in order to create a quality offer.

Keywords: quality of services, quality of health services, SERVQUAL, statistical analysis, Thalassotherapy Opatija. 